\title{
CALIBRATION OF METHODS FOR DESIGNING LARGE-DIAMETER BORED PILES: ULTIMATE LIMIT STATE
}

\author{
L. M. ZHANG ${ }^{\text {i) }}$ and L. F. CHU ${ }^{\text {ii) }}$
}

\begin{abstract}
The development of limit-state design codes for large-diameter bored piles requires a careful calibration of existing design methods. Due to various sources of uncertainty in understanding the geology and construction details, estimation of design loads, and design analysis models and their parameters, the estimated pile capacity values from several design methods for large-diameter bored piles vary widely and the corresponding reliability levels are not clearly known. This paper aims at evaluating the performance of six design methods for bored piles in soils and four design methods for bored piles socketed in rocks based on a database of 62 full-scale load tests on large-diameter bored piles in Hong Kong. These methods include a descriptive method, the $\beta$-method, and several empirical correlations with blow count from the standard penetration test or unconfined compressive strength of rock. The capability of these design methods to estimate individual resistance components and the total capacity is calibrated separately. Construction effects, particularly the use of permanent liners, pile-shaft grouting, and the time delay between the end of pile excavation and pile concreting, are explicitly considered. The performance of each design method is indicated by the first and second moments of the model bias factor, which can be used as a basis for developing partial factors for limit state design.
\end{abstract}

Key words: bored piles, limit state design, pile capacity, piles, reliability, uncertainty (IGC: E4)

\section{INTRODUCTION}

The development of limit-state design codes for largediameter bored piles requires a careful calibration of existing design methods. Several design methods are available for estimating the shaft and toe resistance components of bored piles in soils or rocks, and the design capacity may include one or several resistance components. The most common design method adopted in Hong Kong is a prescriptive method outlined by Buildings Department (BD) (2004a). It provides presumed bearing values for piles on rocks based on local experiences. The O'Neill and Reese (1999) method is commonly used in the US, which adopts the effective stress theory to estimate the shaft resistance in soils and empirical methods to estimate the shaft resistance in rocks and the toe resistance in soils or rocks. Another common practice is to estimate the capacity of bored piles based on empirical correlations with blow count from the standard penetration test (SPT), or the unconfined compressive strength (UCS) of rock.

Various sources of uncertainty exist in the design process. Becker (1996) summarized uncertainties from four major sources: variability of geology, evaluation of soil parameters, estimation of loads, and applicability of de- sign models. Tremendous uncertainty may arise from construction details, which are critical to the performance of bored piles (O'Neill and Reese, 1999). Due to these uncertainties, estimated capacity values from various design methods vary widely and the corresponding pile reliability levels are not clearly known.

In an effort to develop reliability-based design codes in recent years (e.g., Becker, 1996; Honjo et al., 2002; Phoon and Kulhway, 2005; Schuppener, 2007; Honjo and Nagao, 2007), much attention has been paid to the calibration of design methods for different foundation types using reliability principles. Many methods for estimating the bearing capacity of driven piles have been calibrated (e.g., Paikowsky et al., 2004; Zhang et al., 2001). In comparison, only limited effort was paid to calibrate methods for estimating the bearing capacity of large-diameter bored piles (e.g., Withiam et al., 2001; Kuo et al., 2002; Zhang et al., 2002; Foye et al., 2006), possibly because of insufficient load test information and involvement of more uncertainties in construction details.

This paper aims at evaluating the performance of six design methods for bored piles in soils and four design methods for bored piles on rocks based on a database of 62 full-scale load tests on large-diameter bored piles in

i) Associate Professor, Department of Civil and Environmental Engineering, Hong Kong University of Science and Technology, Hong Kong (cezhangl@ust.hk).

ii) Research Assistant, ditto.

The manuscript for this paper was received for review on January 10, 2008; approved on March 26, 2009.

Written discussions on this paper should be submitted before July 1, 2010 to the Japanese Geotechnical Society, 4-38-2, Sengoku, Bunkyo-ku, Tokyo 112-0011, Japan. Upon request the closing date may be extended one month. 


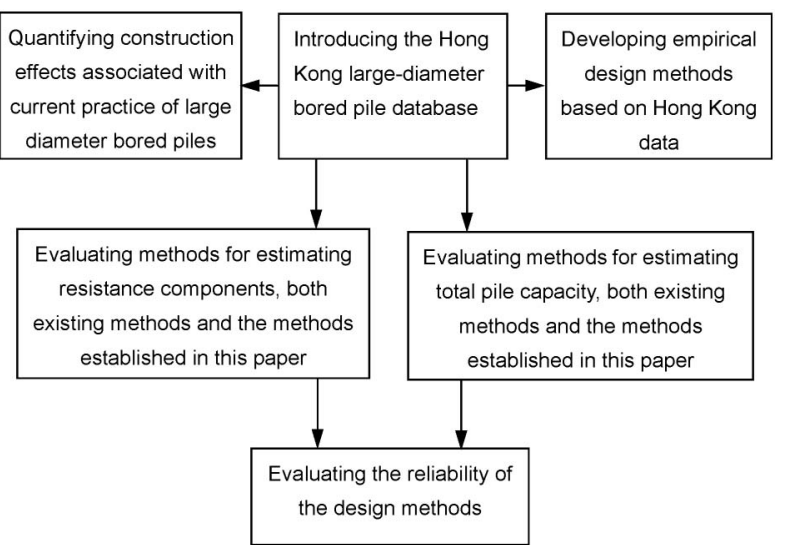

Fig. 1. Flowchart for calibrating methods for designing largediameter bored piles

Hong Kong. These methods include a descriptive method, the $\beta$-method, and several empirical correlations with blow count from the standard penetration test or unconfined compressive strength of rock. A flowchart of the paper is shown in Fig. 1. The construction practice of large-diameter bored piles in Hong Kong is briefly introduced first. A database of 62 static loading tests on large-diameter bored piles and barrettes in Hong Kong is then presented. Based on the information in the database, the construction effects associated with the construction of some pile cases are studied and a number of empirical correlations for pile capacity prediction are established. Subsequently, the capability of the design methods concerned (both existing design methods and the methods developed in this paper) for estimating individual resistance components and the total capacity are calibrated separately. Construction effects, particularly the use of permanent liners, pile-shaft grouting, and the time delay between the end of pile excavation and pile concreting, are explicitly considered during the calibration exercise. Finally, the reliability of piles designed using these methods is evaluated based on the statistics of the model bias factor obtained from the calibration exercise. The calibration of methods for estimating the settlement of large-diameter bored piles is reported separately by Zhang and Chu (2009).

\section{BRIEF DESCRIPTION OF CONSTRUCTION OF BORED PILES}

Large-diameter bored piles are principally designed for resisting heavy superstructural loads. The pile diameter typically ranges from $0.75 \mathrm{~m}$ to $3 \mathrm{~m}$ in Hong Kong, and the pile length can be over $80 \mathrm{~m}$. A pile is constructed either with a uniform section or with an enlarged base (bell-out) that is intended to provide a larger toe capacity. Usually, large-diameter bored piles are founded on rocks and designed as end-bearing piles (BD, 2004a). However, if the bedrock is excessively deep, or the rock conditions cannot meet the criteria stipulated in the Code of Practice for Foundations (COP) (BD, 2004a), the pile capacity

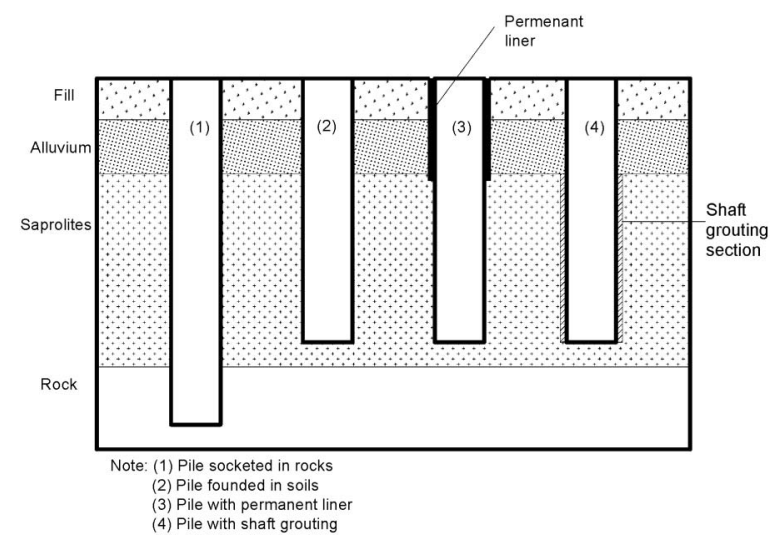

Fig. 2. Large-diameter bored piles with different construction details

can be mainly derived from the shaft resistance along the pile (Lo and Li, 2003).

The pile bore is usually first excavated using rope-operated grabs and chisels. Either a temporary casing or drilling fluid is used to maintain the stability of the pile bore and to minimize stress relief and soil disturbances. When the bedrock is encountered, reverse circulation drilling is commonly used because chiselling in bedrock is prohibited to avoid fracturing of the rock material. Upon reaching the designated design founding level, the pile base must be carefully cleaned. Then, the reinforcement cage is installed in the pile bore. A permanent liner, where necessary, is installed inside the temporary casing. After that, concreting is implemented using high slump concrete through a tremie pipe under water or drilling fluid and the temporary casing is extracted carefully during concreting. If necessary, shaft-grouting or base grouting may be involved to enhance the shaft or toe resistance (e.g., Littlechild et al., 1998; Plumbridge et al., 2000).

Figure 2 shows four scenarios of bored piles in a simplified subsurface condition that is commonly found in Hong Kong. Construction details such as the use of a permanent liner and shaft grouting are illustrated in Fig. 2 as well. An important aspect of bored pile construction is that construction details, such as drilling fluids, pile bore roughness and smear, over-breaking cavities, toe debris cleaning, initial stage of concreting, and delayed removal of casings greatly affect the pile capacity (Poulos and Davis, 1980; O’Neill, 1999, 2001; O'Neill and Reese, 1999; Lo and Li, 2003; Zhang et al., 2006). O'Neill (1999) found that details of pile installation can produce resistances that differ by a factor of 3 to 10 . The uncertainties arising from construction effects often hinder accurate prediction of bored-pile capacity.

\section{LARGE-DIAMETER BORED PILE DATABASE}

\section{Sources of Data}

Information of 62 static loading tests on large-diameter bored piles and barrettes in Hong Kong, in which 56 piles or barrettes were instrumented, was collected for study. Particularly, results of 13 full-scale static loading tests along the West Rail were re-interpreted. The axial load at 
Table 1. Information of piles in soils

\begin{tabular}{|c|c|c|c|c|c|c|c|c|c|}
\hline No. & $\begin{array}{l}\text { Pile } \\
\text { Ref. }\end{array}$ & Site $^{(a)}$ & $\begin{array}{l}\text { Length } \\
(\mathrm{m})\end{array}$ & $\begin{array}{l}\text { Diameter } \\
(\mathrm{m})\end{array}$ & Construction details & $\begin{array}{l}\text { Stratum/soil type } \\
\text { (thickness in meter) }\end{array}$ & $\begin{array}{l}\operatorname{Time}_{(\mathrm{b})}^{(\mathrm{hr})} \\
\mathrm{C}\end{array}$ & Remark & Reference \\
\hline 1 & YCS1 & $\mathrm{NC}$ & 48.8 & 1.5 & $\begin{array}{l}\text { Grabs, RCD } \\
\text { (casing, water) }\end{array}$ & $\begin{array}{l}\text { Fill (15.7), Marine deposit (1), } \\
\text { Alluvium (9.5), } \mathrm{CDG}^{(\mathrm{c})}(22.7)\end{array}$ & 21 & Plain shaft & This study \\
\hline 2 & YCS3R & $\mathrm{NC}$ & 54.4 & 1.3 & Grabs (casing, water) & $\begin{array}{l}\text { Fill (21), Marine deposit (0.9), } \\
\text { Alluvium (1.1), CDG (31.4) }\end{array}$ & 66 & $\begin{array}{l}\text { Shaft } \\
\text { grouted }\end{array}$ & This study \\
\hline 3 & TSW2L & TSW & 30.2 & 1.5 & Grabs (casing, water) & $\begin{array}{l}\text { Fill (4.5), Alluvium (3.0), } \\
\text { Metasiltstone (22.7) }\end{array}$ & 156 & $\begin{array}{l}\text { Shaft } \\
\text { grouted }\end{array}$ & This study \\
\hline 4 & TP1a & $\mathrm{TC}$ & 38.5 & 1.2 & Grabs (casing, water) & $\begin{array}{l}\text { Fill (0.6), Alluvium (10.5), } \\
\mathrm{CDV}^{(\mathrm{c})}(27.8)\end{array}$ & 24 & With liner & This study \\
\hline 5 & TP2 & $\mathrm{TC}$ & 25.5 & 1.2 & Grabs (casing, water) & $\begin{array}{l}\text { Fill (5.4), Alluvium (12.7), } \\
\text { CDV (7.5) }\end{array}$ & 60 & With liner & This study \\
\hline 6 & TP1 & $\mathrm{TC}$ & 39.3 & 1.2 & Grabs (casing, water) & $\begin{array}{l}\text { Fill (2.2), Alluvium (9.6), CDV } \\
(27.5)\end{array}$ & 216 & With liner & This study \\
\hline 7 & YUL2 & YL & 31.8 & 1.2 & Grabs (casing, water) & $\begin{array}{l}\text { Fill (3.1), Alluvium (10.8), } \\
\text { CDV (18.0) }\end{array}$ & 48 & $\begin{array}{l}\text { Shaft } \\
\text { grouted }\end{array}$ & This study \\
\hline 8 & SYP1 & WHC & 45.0 & 1.8 & Grabs (casing, water) & $\begin{array}{l}\text { Fill (10.0), Marine deposit (3.0), } \\
\text { Alluvium (2.0), CDG (30.0) }\end{array}$ & - & With liner & $\begin{array}{l}\text { Silva et al. } \\
\text { (1998) }\end{array}$ \\
\hline 9 & La7a & TG & 36.9 & 1.0 & Grabs (casing, water) & $\begin{array}{l}\text { Fill (14.0, Alluvium \& Marine } \\
\text { deposit (11.0), CDG (12.0) }\end{array}$ & - & Plain shaft & $\begin{array}{l}\text { Holt et al. } \\
\text { (1982) }\end{array}$ \\
\hline 10 & $\mathrm{H} 25$ & TG & 16.8 & 1.5 & Grabs (casing, water) & $\begin{array}{l}\text { Fill (7.3), Alluvium \& Marine } \\
\text { deposit (7.3), CDG (2.2) }\end{array}$ & - & Plain shaft & $\begin{array}{l}\text { Holt et al. } \\
\text { (1982) }\end{array}$ \\
\hline 11 & K27 & TG & 17.3 & 1.5 & Grabs (casing, water) & $\begin{array}{l}\text { Fill (4.4), Alluvium \& Marine } \\
\text { deposit (4.5), CDG (8.4) }\end{array}$ & - & Plain shaft & $\begin{array}{l}\text { Holt et al. } \\
\text { (1982) }\end{array}$ \\
\hline 12 & $\mathrm{~L} 23$ & TG & 25.1 & 1.5 & Grabs (casing, water) & $\begin{array}{l}\text { Fill (13.3), Alluvium \& Marine } \\
\text { deposit (7.0), CDG (4.8) }\end{array}$ & - & Plain shaft & $\begin{array}{l}\text { Holt et al. } \\
\text { (1982) }\end{array}$ \\
\hline 13 & Ja6a & TG & 42.0 & 1.0 & Grabs (casing, water) & $\begin{array}{l}\text { Fill (14.0), Alluvium \& Marine } \\
\text { deposit (8.0), CDG (20.0) }\end{array}$ & - & Plain shaft & $\begin{array}{l}\text { Holt et al. } \\
\text { (1982) }\end{array}$ \\
\hline 14 & $\mathrm{~J} 22 \mathrm{a}$ & TG & 21.2 & 1.2 & Grabs (casing, water) & $\begin{array}{l}\text { Fill (6.1), Alluvium \& Marine } \\
\text { deposit (6.1), CDG (9.0) }\end{array}$ & - & Plain shaft & $\begin{array}{l}\text { Holt et al. } \\
\text { (1982) }\end{array}$ \\
\hline 15 & TG & TG & 64.2 & 1.0 & Grabs (casing, water) & $\begin{array}{l}\text { Fill (14), Alluvium \& Marine } \\
\text { deposit (14.2), CDG (36.0) }\end{array}$ & - & Plain shaft & $\begin{array}{l}\text { Holt et al. } \\
\text { (1982) }\end{array}$ \\
\hline 16 & $17-4$ & WKC & 43.5 & 1.5 & Grabs (casing, water) & Fill (29.0), CDG (14.5) & - & Plain shaft & $\begin{array}{l}\text { Fraser and } \\
\text { Kwok (1986) }\end{array}$ \\
\hline 17 & C8-7-1 & WKC & 51.6 & 1.5 & $\begin{array}{l}\text { Grabs, RCD } \\
\text { (casing, water) }\end{array}$ & $\begin{array}{l}\text { Fill (10.0), Marine deposit ( } 3.5) \text {, } \\
\text { Alluvium (5.5), Residual soil } \\
(10.0), \text { CDG (22.7) }\end{array}$ & - & With liner & $\begin{array}{l}\text { Fraser and } \\
\text { Kwok (1986) }\end{array}$ \\
\hline 18 & $\mathrm{~A} 2 / 3$ & IEC & 65.9 & 1.5 & Grabs (casing) & $\begin{array}{l}\text { Fill (11.1), Alluvium (7.9), } \\
\text { CDG (37.4), } \text { HDG }^{(c)}(9.4)\end{array}$ & - & Plain shaft & Fraser (1985) \\
\hline 19 & MOS1 & MOS & 72.7 & 1.5 & Grabs (bentonite) & $\begin{array}{l}\text { Fill (12.5), Marine deposit (0.1), } \\
\text { Alluvium (15.9), CDG (44.2) }\end{array}$ & - & With liner & $\begin{array}{l}\text { Chan et al. } \\
(2002)\end{array}$ \\
\hline 20 & MTR1 & FPMTR & 36.9 & 1.0 & - & $\begin{array}{l}\text { Fill (11.7), Alluvium (12.1), } \\
\text { CDG (26.7) }\end{array}$ & - & - & Linney (1983) \\
\hline
\end{tabular}

Note: (a) $\mathrm{NC}=$ Nam Cheong Station; $\mathrm{TSW}=$ Tsuen Wan West Station; $\mathrm{TC}=$ Tung Chung Station; $\mathrm{YL}=$ Yuen Long Station; WHC $=$ Western Harbour Corridor; TG = Telford Garden; WKC = West Kowloon Corridor; IEC = Island Eastern Corridor; MOS = Ma On Shan Rail; FPMTR = First Phase of Mass Transit Railway.

(b) Time between the end of pile bore excavation and concreting.

(c) $\mathrm{CDG}=$ completely decomposed granite; $\mathrm{HDG}=$ highly decomposed granites; $\mathrm{CDV}=$ completely decomposed volcanics.

a particular pile section can be calculated using the strain gauge data at that section, which are calibrated based on the response of the top-level strain gauges against known applied loads. The local pile displacement at a particular pile section can be calculated by subtracting the elastic pile shortening calculated using the strain measurements above the section from the pile-head settlement. The unit shaft resistance between any two levels of strain gauges can be calculated based on the readings from these strain gauges.

As method of installation has significant effects on the performance of bored piles, only the results of loading tests on piles constructed by grabs and reverse circulation drilling under water or bentonite were used. The ground profile usually consists of fill, alluvium, saprolites and rocks, as illustrated in Fig. 2. Saprolites refer to a soil mass that retains original texture, fabric and structure of parent rock, and are generally regarded as granular soils in terms of their engineering behaviour (GEO, 2006). The test piles were founded in a wide range of soil types and rock types including igneous and metamorphic rocks. Tables 1 and 2 summarize the pile cases founded in soils and rocks, respectively. Among the test piles, 38 piles are founded in soils, 7 additional piles in soils with shaft grouting, and the remaining 17 piles socketed in rocks. The pile diameter ranges from 1.0 to $1.8 \mathrm{~m}$ and the pile length is up to $72.7 \mathrm{~m}$.

\section{Organization of the Database}

A pile is either classified as being founded in soils or founded on rocks depending on the ground conditions at its founding level. Piles are designed as end-bearing piles on rocks only when the rock conditions meet the quality criteria stipulated in the COP in terms of weathering degree, UCS, total core recovery (TCR) and other indices. Otherwise, a significant part of the capacity will be 
Table 2. Information of piles in rocks

\begin{tabular}{|c|c|c|c|c|c|c|c|c|c|c|c|c|}
\hline No. & $\begin{array}{l}\text { Pile } \\
\text { Ref }^{(a)}\end{array}$ & $\begin{array}{l}\text { Length } \\
\text { (m) }\end{array}$ & $\begin{array}{l}\text { Diameter } \\
(\mathrm{m})\end{array}$ & $\begin{array}{l}\text { Socket } \\
\text { length } \\
\text { (m) }\end{array}$ & $\begin{array}{l}\text { Permanent liner } \\
\text { installation }\end{array}$ & $\begin{array}{c}\text { Toe } \\
\text { UCS } \\
(\mathrm{MPa})\end{array}$ & $\begin{array}{c}\text { Toe } \\
\text { RQD } \\
(\%)\end{array}$ & $\begin{array}{l}\text { Socket } \\
\text { UCS } \\
(\mathrm{MPa})\end{array}$ & $\begin{array}{c}\text { Socket } \\
\text { RQD } \\
(\%)\end{array}$ & $\begin{array}{c}\mathrm{RMR} \\
(\%)\end{array}$ & $\begin{array}{c}\mathrm{E} \\
(\mathrm{GPa})\end{array}$ & Reference \\
\hline 1 & TP1-TY & 24.7 & 1.20 & 1.5 & Up to rock socket & 200 & - & - & - & - & 1.5 & Hope et al. (2000) \\
\hline 2 & TP2-TY & 24.5 & 1.20 & 3.0 & Up to rock socket & 40 & - & 35 & - & - & 0.7 & Hope et al. (2000) \\
\hline 3 & TP3-K & 38.6 & 1.20 & 1.2 & Up to rock socket & 70 & 100 & 83 & 100 & 79 & 2.5 & Hope et al. (2000) \\
\hline 4 & TP4-K & 60.3 & 1.20 & 3.5 & Up to rock socket & - & 29 & - & 70 & 17 & 0.3 & Hope et al. (2000) \\
\hline 5 & TP5-C & 43.1 & 1.00 & 0.9 & Up to rock socket & 150 & 100 & 150 & 95 & 79 & 5.1 & Hope et al. (2000) \\
\hline 6 & TP6-C & 49.3 & 1.00 & 2.5 & Up to rock socket & 80 & 91 & 25 & 96 & 72 & 1.2 & Hope et al. (2000) \\
\hline 7 & TMC 1 & 28.1 & 1.30 & 2.1 & Up to rock socket & 202 & 60 & 105 & 71 & 73 & 2.5 & This study \\
\hline 8 & TMC 2 & 32.5 & 1.20 & 1.9 & Up to top of saprolites & 190 & 90 & 129 & 45 & - & - & This study \\
\hline 9 & TWW 1 & 23.1 & 1.32 & 2.0 & Up to rock socket & 15 & 49 & 35 & 0 & 27 & 0.5 & This study \\
\hline 10 & TSW 1 & 39.9 & 1.20 & 1.5 & Up to rock socket & 62 & 50 & 29 & 55 & 59 & 1.3 & This study \\
\hline 11 & TSW 2 & 39.4 & 1.35 & 0.7 & No liner & 26 & 88 & - & - & 58 & 9.0 & This study \\
\hline 12 & YUL 1 & 40.6 & 1.20 & 0.7 & No liner & 42 & 83 & - & - & 51 & 5.8 & This study \\
\hline 13 & LOP 1 & 69.9 & 1.20 & 0.6 & No liner & 30 & 84 & - & - & 51 & 1.6 & This study \\
\hline 14 & TMN 1 & 30.2 & 1.20 & 1.1 & Up to rock socket & 137 & 46 & - & - & - & - & This study \\
\hline 15 & YCS1 & 49.4 & 1.5 & 2.0 & No liner & 15 & 49 & - & - & - & 1.0 & This study \\
\hline 16 & VT 1 & 37.1 & 1.00 & 0.5 & Whole pile & 35 & 31 & - & - & - & 5.7 & Zhan and Yin (2000) \\
\hline 17 & VT 2 & 35.6 & 1.00 & 2.0 & Up to rock socket & 81 & 60 & 87 & 55 & - & 7.3 & Zhan and Yin (2000) \\
\hline
\end{tabular}

Note: (a) TY = Tsing Yi Station; $\mathrm{K}=$ Kowloon Station; $\mathrm{C}=$ Central Station; TMC = Tuen Mun Central Station; TWW $=$ Tsuen Wan West Station; TSW = Tin Shui Wai Station; YUL = Yuen Long Station; LOP = Long Ping Station; TMN = Tuen Mun North; YCS = Yen Chow Street; VT = Tseung Kwan O Station.

derived from the shaft resistance in soil layers. As the major contribution to the capacity of these two types of piles is from different components, the two types of piles are studied separately.

Pile dimensions, construction details, and ground conditions are gathered for the database. The database also contains information of load transfer curves, maximum mobilized average shaft resistance and its corresponding local displacement, as well as mobilized end bearing resistance and its corresponding toe displacement. In addition, parameters related to the shear strength of soil or rock materials are also gathered. For piles in soils, the uncorrected Standard Penetration Test blow count (SPT- $\bar{N}$ ) is commonly used to represent the soil shear strength. Therefore, SPT $-\bar{N}$ values for all soil layers are collected, if available. Shaft grouted piles in soils are also classified as piles in soils. For piles on rocks, the information of weathering degree, UCS, TCR, rock quality designation (RQD) and rock mass rating (RMR) is collected, if available.

For the piles in soils, the shaft resistance is usually contributed from multiple soil layers. As different soil layers exhibit different engineering properties, load test results for the piles in soils are further analyzed for each soil type (i.e., fill, alluvium, decomposed volcanics, decomposed granitic soils).

\section{Definition of Pile Failure}

In the past, several failure criteria were used to interpret pile failure in Hong Kong, such as Brinch Hansen's 80\% criterion (Brinch Hansen, 1963) and Buildings Department's criteria (BD, 2004a). Ng et al. (2001) reviewed the applicability of these criteria to large-diameter bored piles. The ultimate shaft and toe resistances of a pile are calculated based on instrumented load test results at the interpreted failure load. However, pile failures de- fined by some of these failure criteria were not achieved in some load tests. Accordingly, the ultimate shaft and toe resistances were often not fully mobilized; particularly, the toe resistance was often far from being fully mobilized. Therefore, in the correlation study that will be reported later, the maximum test load was taken to be the ultimate load if the test pile had not been loaded to failure. In doing so, the ultimate resistance was often underestimated. The underestimation due to the use of failure criteria can be quantified by a bias factor (Zhang and Tang, 2001; Zhang et al., 2005).

\section{Quantification of Construction Effects}

In this paper, three construction effects (i.e., construction time, use of permanent liner, and pile shaft grouting) are quantified. In the design of bored piles, the effects of these construction details are generally not included through soil parameters derived from laboratory tests or in-situ tests.

After the excavation of pile bore is completed, verifying the founding stratum, cleaning the pile base, and installing the reinforcement cage are carried out before concreting. A long construction time in between may result in time-dependent lateral stress relief in the soil surrounding the pile bore and lead to a reduction of the shear strength of the soil (O'Neill, 1999). Figure 3(a) shows the relationship between the shaft resistance measured from static loading tests at two sites and the construction time between the end of pile-bore excavation and concreting. The shaft resistance decreases with the construction time at both sites. For the piles in decomposed volcanics, stress relief might not be the only reason for the loss of capacity. To ensure easy extraction during concreting, the temporary casing was twisted, lifted and pushed down several times using an oscillator. The process caused disturbance to the soil and led to further loss 

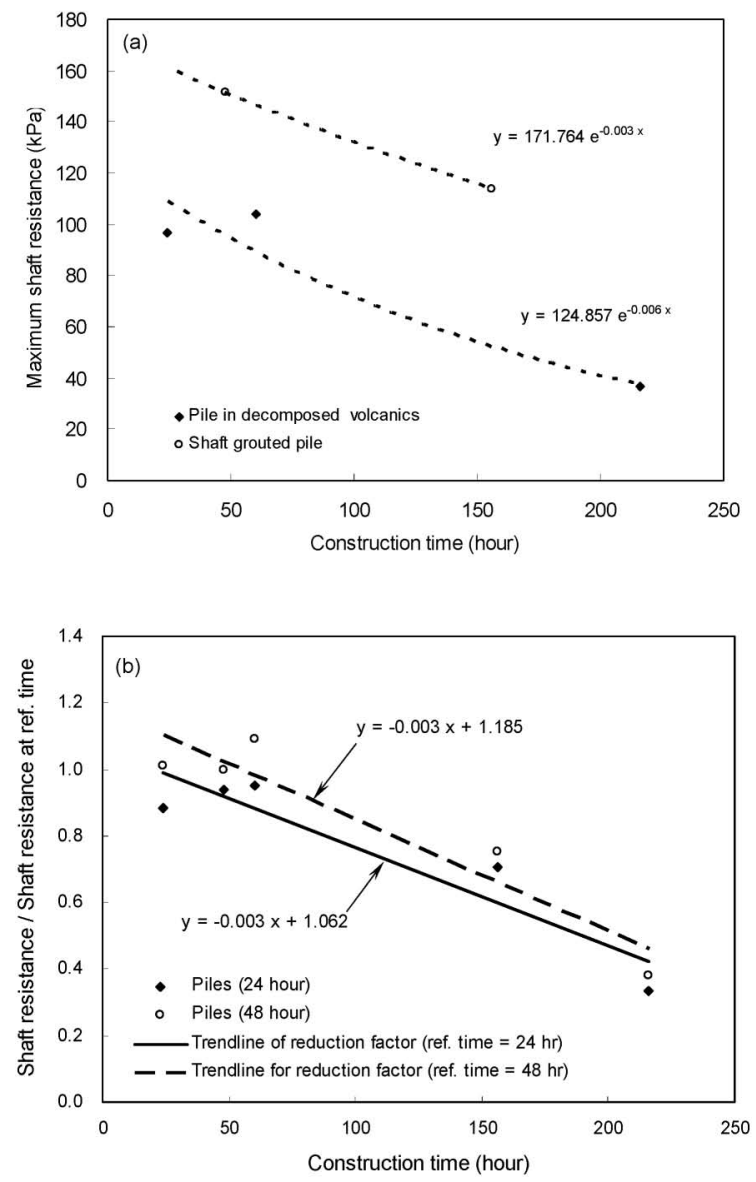

Fig. 3. (a) Change of the maximum shaft resistance with the construction time between the end of excavation and concreting and (b) Reduction factor for considering the effect of construction time using reference construction times of 24 hours and 48 hours

of axial capacity. To quantify the effects of construction time, a reduction factor, plotted in Fig. 3(b), is used to compare the shaft resistance for a particular construction time with that for a reference construction time. The reference construction time is based on the normal construction period, which is taken as 24 or 48 hours.

The second and third construction effects are the use of permanent liners and pile shaft grouting, respectively. A permanent liner is often used to retain unstable soil that is likely to collapse into fresh concrete and create structural imperfections in the pile. Lo and Li (2003) showed that the use of a permanent liner can lead to loss of pile capacity. On the other hand, post-construction pile shaft grouting can significantly increase the pile shaft resistance. Therefore, in developing correlative relations for pile shaft resistance and in calibrating each design method, test data from pile segments with and without the use of permanent liners or shaft grouting were grouped and studied separately in this paper.

\section{Correlation Study}

Theoretical methods are capable of predicting the base behaviour of bored piles in a rational manner as long as the designers can predict the effects of stress relief and disturbance on properties of the soil at the base (O'Neill,
1999). However, those effects are not easy to quantify. Instead, empirical correlations provide another means to estimate the behaviour of bored piles with implicit consideration of the construction effects.

In this study, a correlation study was performed to derive empirical relations for calculating the shaft and toe resistances of large-diameter bored piles. For the shaft resistance in soil, as different soils exhibit different engineering properties, the measured maximum average shaft resistance in each soil layer was correlated with $\bar{N}$ and or the effective vertical soil stress $\sigma_{v}^{\prime}$ at the centre of the layer for different types of soils including fill, alluvium, decomposed volcanics, and decomposed granites. The toe resistance was correlated with $\sigma_{v}^{\prime}$ at the base. Moreover, as the use of permanent liners may cause loss of axial capacity, load test results of piles with liners and piles without liners were separated in the correlation study. Figures 4 and 5 show these correlations.

For piles socketed in rocks, load test results of the piles with liners up to the rock socket and the piles without liners were separated in the correlation study. The shaft resistance along the rock socket and the toe resistance were assumed to be mobilized simultaneously. A correlation study was also preformed to establish the relations between the pile resistances and UCS. The relations are plotted in Figs. 6 and 7. Besides, the end bearing resistance is correlated with RMR as shown in Table 4. RMR accounts for the effect of joint orientation on the pile capacity (Bieniawski and Orr, 1976). The established empirical relations, as well as existing design equations, are summarized in Table 3 for piles in soils and in Table 4 for piles socketed in rocks.

\section{DESIGN METHODS UNDER CALIBRATION}

\section{Code of Practice for Foundations (BD, 2004a)}

The allowable capacity of the soil/rock under working loads where any foundation is founded shall be the lesser of:

1. The ultimate capacity for bearing, bond or friction with an adequate factor of safety against failure; or

2. The value in relation to bearing, bond or friction such that the maximum deformation or movement induced to the foundation under working loads can be tolerated by the building, any other building structure, land, street and services.

The Code of Practice for Foundations (BD, 2004a) classifies rocks into four categories in terms of their weathering degree, strength, and total core recovery. A set of allowable vertical pressures for foundations on horizontal ground is estimated based on empirical correlations. Table 4 summarizes the details of rock classification and presumed bearing stress values in the Code of Practice for Foundations. The capacity of the pile is taken as the sum of the frictional resistance of the rock socket and the end bearing resistance. The presumed allowable vertical bearing pressures are suggested for rocks, intermediate soils in decomposed granite and decomposed volcanics, non-cohesive soils, and cohesive 

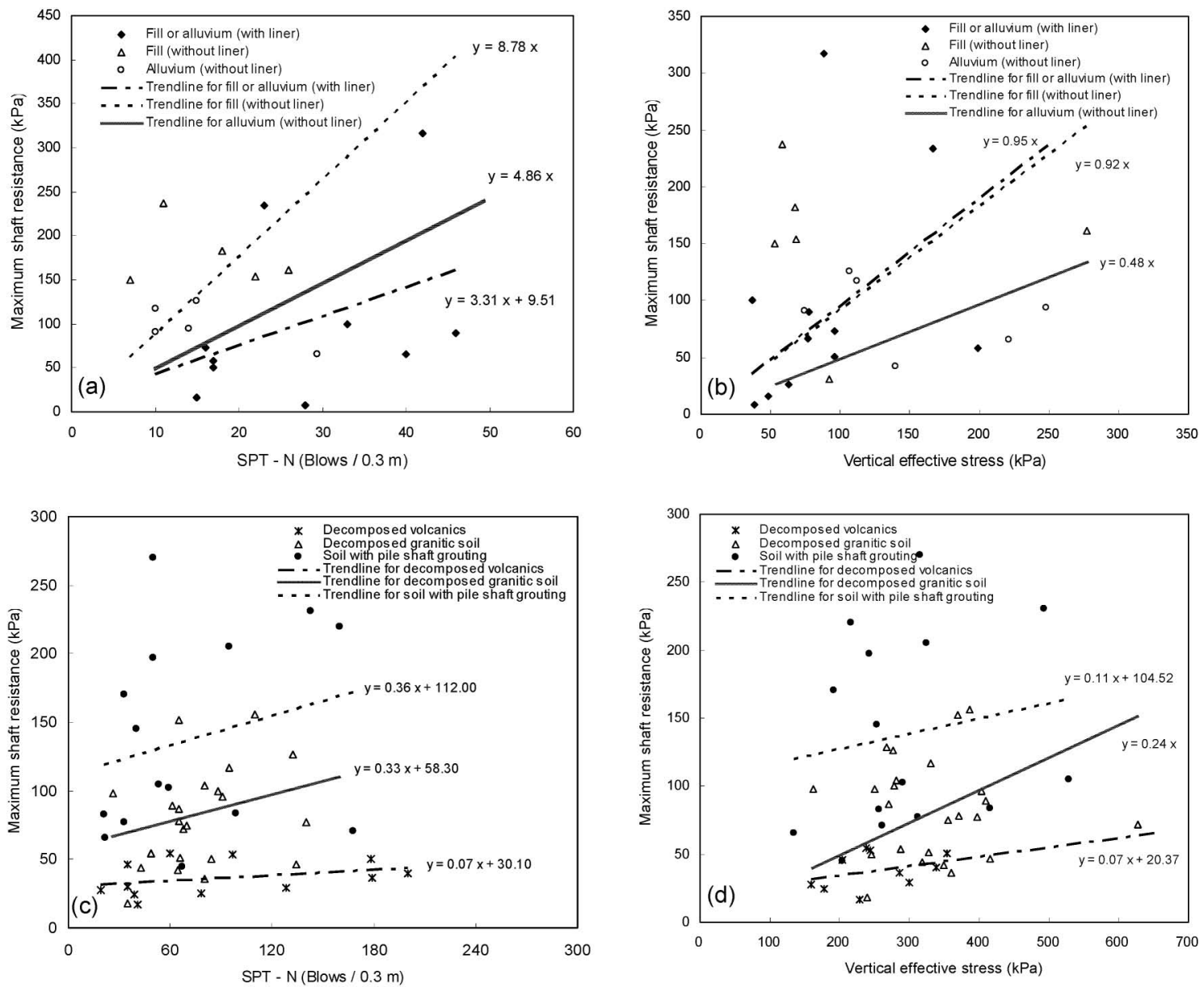

Fig. 4. Correlations between maximum unit shaft resistance and (a) SPT- $N$ in fill and alluvium, (b) vertical effective stress in fill and alluvium, (c) SPT $-N$ in CDV, CDG and cases with pile shaft grouting and (d) vertical effective stress in CDV, CDG and cases with pile shaft grouting

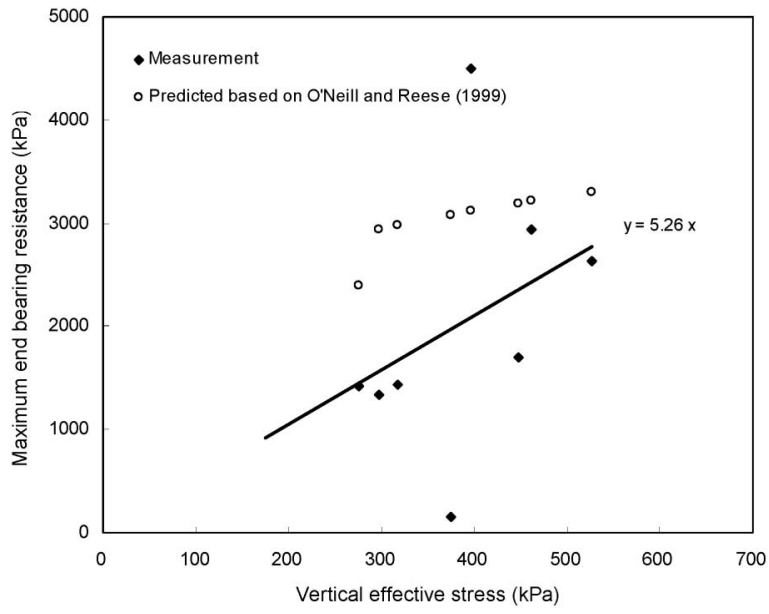

Fig. 5. Correlation between unit toe resistance in soil and vertical effective stress

soils. The presumed allowable bond or friction between ground and pile is only suggested for rock socket and its magnitude is defined based on the quality of rock mass. The socket length providing the frictional resistance is limited to two pile diameters or $6 \mathrm{~m}$, whichever is shorter. However, the contribution from the minimum socket

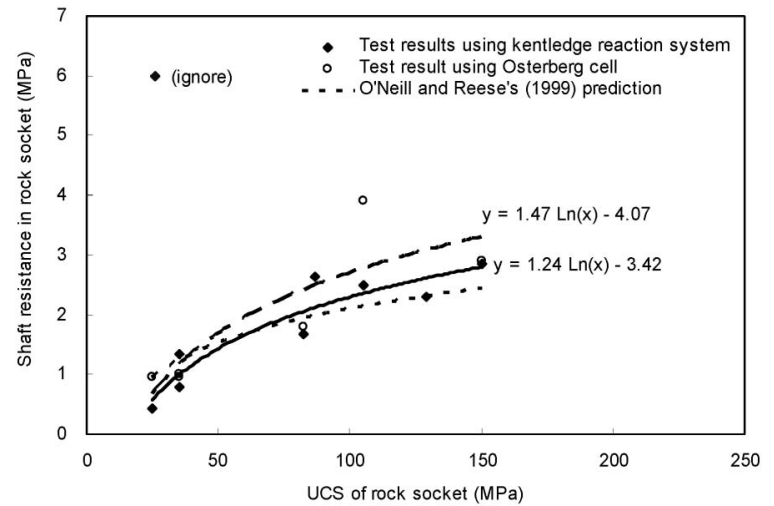

Fig. 6. Correlations between maximum unit shaft resistance along rock socket and average unconfined compressive strength of rock

length and the inclined faces of a bell-out is ignored in the estimation of the pile capacity. These suggested presumed values are only applicable to structures that are not sensitive to settlements or other displacements that are required for mobilization of the bearing capacity. They can be used without settlement check for structures that are not unduly sensitive to settlement. 


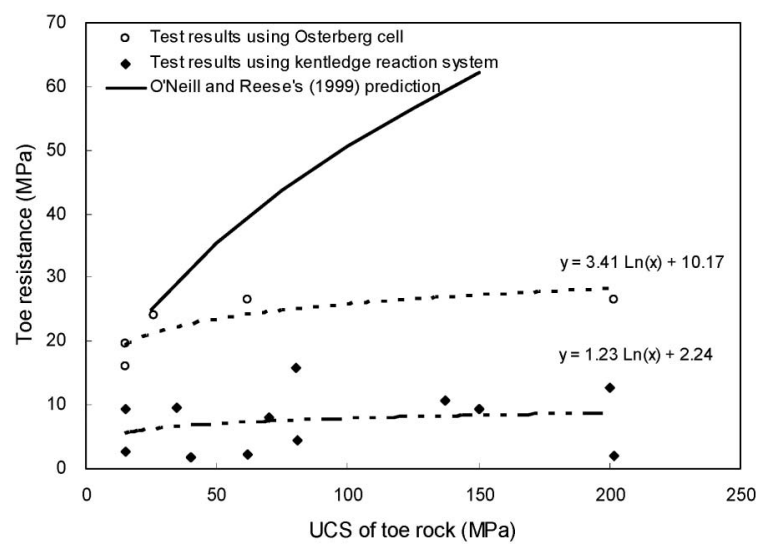

Fig. 7. Correlations between maximum unit toe resistance in rock and average unconfined compressive strength of rock

\section{The O'Neill and Reese (1999) Method}

The geomaterials around the pile are first identified and simplified into several layers based on their characteristics. Each layer is then classified into one of the following categories (O’Neill and Reese, 1999):

1. Cohesive soil (clay or plastic silt with undrained shear strength $\left.S_{\mathrm{u}} \leq 0.25 \mathrm{MPa}\right)$

2. Granular soil (sand, non-plastic silt or gravel with SPT $-N \leq 50$ blows/ $0.3 \mathrm{~m})$;

3. Intermediate geomaterial (cohesive material with $0.25 \leq S_{\mathrm{u}} \leq 2.5 \mathrm{MPa}$, or cohesionless material with $\mathrm{SPT}-N \geq 50$ blows $/ 0.3 \mathrm{~m})$;

4. Rock (cohesive, cemented geomaterial with $S_{\mathrm{u}} \geq 2.5$ $\mathrm{MPa}$ or $\mathrm{UCS} \geq 5.0 \mathrm{MPa}$ ).

The capacity of a bored pile is the sum of the shaft resistance computed for each layer and the toe resistance

Table 3. Design methods for piles in soils considered in the calibration exercise

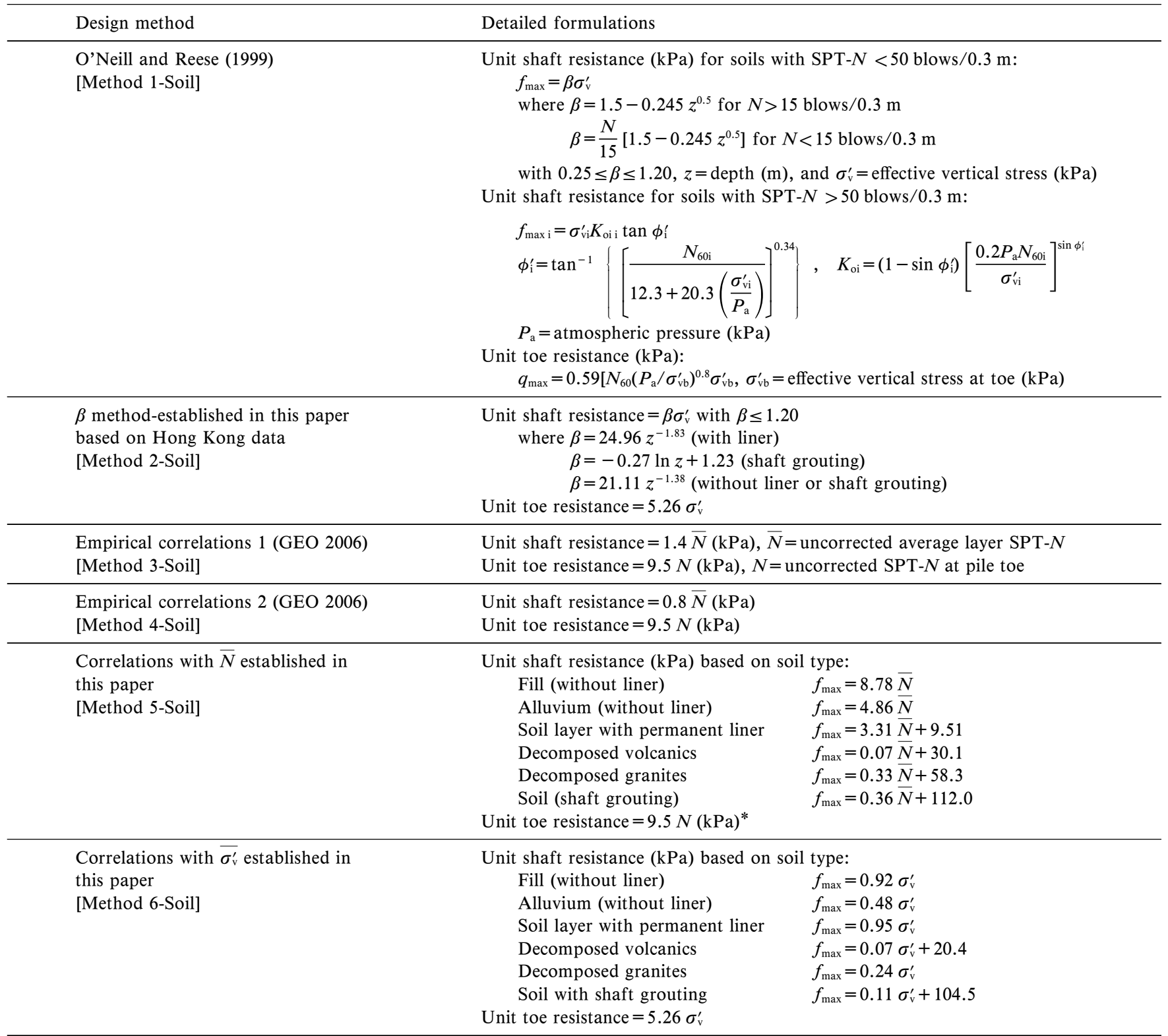

* due to the limited data for correlation study between the end bearing resistance and the SPT- $N$ values, the empirical correlation for estimating the end bearing resistance suggested in Foundation Design and Construction (GEO 2006) is used. 
Table 4. Design methods for piles socketed in rocks considered in the calibration exercise

\begin{tabular}{|c|c|c|c|}
\hline Design method & \multicolumn{3}{|c|}{ Detailed formulations } \\
\hline \multirow{9}{*}{$\begin{array}{l}\text { Code of Practice for Foundations } \\
\text { (BD 2004a) } \\
\text { [Method 1-Rock] }\end{array}$} & \multicolumn{3}{|c|}{ End bearing resistance } \\
\hline & Category & Description & Presumed bearing stress $(\mathrm{kPa})$ \\
\hline & 1(a) & $\begin{array}{l}\text { Fresh strong to very strong rock } \\
\text { Weathering grade I } \\
\text { No weathering joints } \\
\text { Total Core Recovery }=100 \% \\
\text { UCS }>75 \mathrm{MPa}\end{array}$ & 10,000 \\
\hline & $1(b)$ & $\begin{array}{l}\text { Fresh to slightly decomposed strong rock } \\
\text { Weathering grade II or better } \\
\text { Total Core Recovery }>95 \% \\
\text { UCS }>50 \mathrm{MPa}\end{array}$ & 7,500 \\
\hline & $1(\mathrm{c})$ & $\begin{array}{l}\text { Slightly to moderately decomposed, } \\
\text { moderately strong rock } \\
\text { Weathering degree III or better } \\
\text { Total Core Recovery }>85 \% \\
\text { UCS }>25 \mathrm{MPa}\end{array}$ & 5,000 \\
\hline & $1(\mathrm{~d})$ & $\begin{array}{l}\text { Moderately decomposed, moderately } \\
\text { strong to moderately weak rock } \\
\text { Weathering grade better than IV } \\
\text { Total Core Recovery }>50 \%\end{array}$ & 3,000 \\
\hline & \multicolumn{3}{|c|}{ Shaft resistance in rock socket } \\
\hline & Category & \multicolumn{2}{|c|}{ Presumed allowable friction between rock and concrete $(\mathrm{kPa})$} \\
\hline & $\begin{array}{l}\text { 1(c) or better } \\
1(\mathrm{~d})\end{array}$ & \multicolumn{2}{|c|}{$\begin{array}{l}700 \\
300\end{array}$} \\
\hline $\begin{array}{l}\text { O'Neill and Reese (1999) } \\
\text { [Method 2-Rock] }\end{array}$ & \multicolumn{3}{|c|}{$\begin{array}{l}\text { where } f_{\mathrm{c}}^{\prime}=\text { compressive cylinder strength of the pile concrete; } \\
\quad P_{\mathrm{a}}=\text { atmospheric pressure. } \\
\text { Unit end bearing resistance }(\mathrm{MPa}) \text { : } \\
q_{\max }=4.83 \mathrm{UCS}(\mathrm{MPa})^{0.51}\end{array}$} \\
\hline $\begin{array}{l}\text { Correlations with UCS }(\mathrm{MPa}) \text { of } \\
\text { rock established in this paper } \\
\text { [Method 3-Rock] }\end{array}$ & \multicolumn{3}{|c|}{ 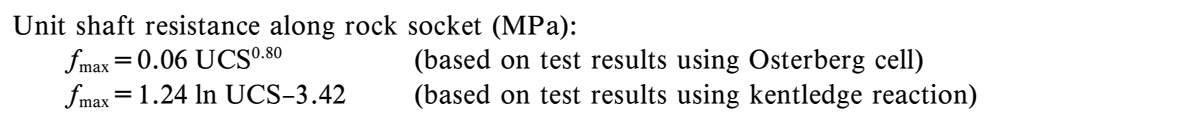 } \\
\hline $\begin{array}{l}\text { Correlations with RMR (\%) of } \\
\text { rock established in this paper } \\
\text { [Method 4-Rock] }\end{array}$ & 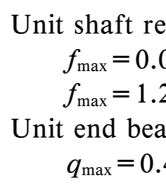 & $\begin{array}{l}\text { nce along rock socket }(\mathrm{MPa}) \text { : } \\
\text { CS } \\
\text { UCS-3.42 } \quad \text { (based on test result using } \mathrm{C} \\
\text { resistance (MPa): } \\
\mathrm{MR}^{0.95}\end{array}$ & $\begin{array}{l}\text { berg cell) } \\
\text { dge reaction) }\end{array}$ \\
\hline
\end{tabular}

computed for the layer in which the base is placed. The design equations of the O'Neill and Reese method for bored piles in soils are summarized in Table 3. A simplified $\beta$ method is adopted to calculate the shaft resistance in granular soils. $\beta$ decreases non-linearly with depth and is limited between 0.25 and 1.2 in sands based on the study of O'Neill and Hassan (1994).

O'Neill and Hassan (1994) provided insufficient data to support $\beta$ values beyond $26 \mathrm{~m}$ depth and to include construction effects. Most bored piles in Hong Kong are, however, longer than $26 \mathrm{~m}$ and affected by such construction details as the use of permanent liners and shaft grouting. In this study, $\beta$ values are back calculated based on load tests in Hong Kong on piles with permanent liners, shaft grouting, and none of them separately. Figure 8 presents the Hong Kong $\beta$ values and a comparison of the Hong Kong trendlines with that suggested by O'Neill and Reese (1999). The Hong Kong $\beta$ values cover pile depths up to $72.7 \mathrm{~m}$. From Fig. 8, the Hong Kong trendline for piles without liners or shaft grouting is indeed comparable to the O'Neill and Reese recommendation. The use of permanent liners results in lower $\beta$ values, particularly at large depths; this is expected as permanent liners can lead to reduced effective radial 


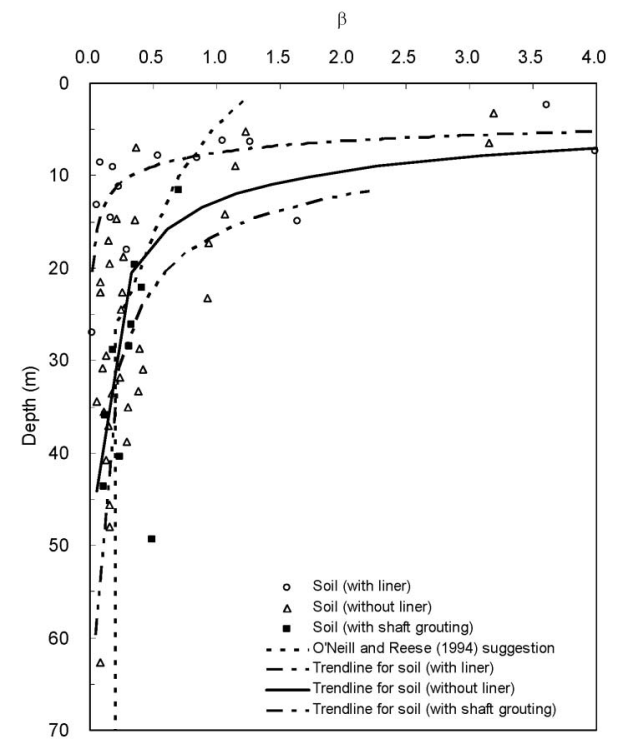

Fig. 8. Variation of back-calculated $\beta$ values with depth based on load tests in Hong Kong

stresses around the pile shaft (Lo and $\mathrm{Li}, 2003$ ). On the contrary, larger $\beta$ values are obtained with the use of shaft grouting. The equations for the Hong Kong trendlines are summarized in Table 3.

The design equations of the O'Neill and Reese method for bored piles socketed in rocks are summarized in Table 4. The empirical correlation with UCS proposed by Horvath and Kenney (1979) based on load tests on piles socketed in shale are adopted to estimate the shaft resistance in rock socket. A number of correlations that are based on experimental studies on bored piles are used to estimate the toe resistances in intermediate geomaterials and rocks.

\section{Correlations with SPT-N or UCS based on Hong Kong Test Data}

SPT- $N$ and UCS are commonly used to represent the strength of soils and rocks, respectively. Many empirical correlations have been suggested to relate the pile resistance with these two indicators. Based on previous loading tests on instrumented large-diameter bored piles, GEO (2006) found that the ratio of the average mobilized shaft resistance $\tau$ (in $\mathrm{kPa}$ ) to $\bar{N}$ generally ranges between 0.8 and 1.4 regardless of the soil type; while the ratio of the toe resistance (in $\mathrm{kPa}$ ) to $\bar{N}$ is in the range of $6-13$ at a toe settlement of $1 \%$ of pile diameter. The shaft resistance in the rock socket and the toe resistance on rock are also correlated to UCS or the rock mass rating (RMR).

In this paper, several new empirical relations for calculating shaft and toe resistances of piles in both soils and rocks were established based on the Hong Kong bored pile database. These relations are shown in Figs. 4-7 and summarized in Tables 3 and 4.

\section{EVALUATION OF METHODS FOR ESTIMATING RESISTANCE COMPONENTS}

Each of the equations in Tables 3 and 4 can be used to estimate one resistance component, either the shaft resistance or the toe resistance. The accuracy of estimation using any of these equations was evaluated by comparing the estimates against the respective field measurements. More specifically, the accuracy of a design equation is measured by a model bias factor that is defined as the ratio of measured resistance to estimated resistance. The first and second moments of the model bias factor indicate the deviation between the measured and estimated resistances.

Using the test results in the load test database, the model bias factors for the six methods in Table 3 for estimating shaft resistances in various soils were studied. The mean, standard deviation, and coefficient of variation (COV) of the model bias factor for each design method are shown in Tables 5-7. Analysis has been performed for the four soil types (i.e., fill, alluvium, decomposed volcanics, and decomposed granites) and for shaftgrouted piles separately. The degree of dispersion of all these methods is quite large; the COV ranges from 0.32 to 0.75 for decomposed volcanic and granite. Notably, very few test cases for shaft resistances in fill and alluvium are available and the COV values from the limited data are rather large. The large COV values infer that our ability to predict the shaft resistance of large-diameter bored piles is still rather limited and much attention should be paid to better understand the construction effects. Note that sufficient data are not available in this study to evaluate the accuracy of the models for estimating the pile toe resistance in soils.

Similar to the design methods for piles in soils, the accuracy of the four design methods in Table 4 for estimating the shaft and toe resistances of rock sockets was evaluated, as shown in Table 8. The COV ranges from 0.23 to 0.78 . The correlations with UCS or RMR yield good predictions with $\mathrm{COV}$ values of 0.23 for the rock-socket shaft resistance and 0.25 for the toe resistance on rock.

\section{EVALUATION OF METHODS FOR ESTIMATING TOTAL PILE CAPACITY}

In practical design, the total pile capacity may be calculated using a combination of various design equations for estimating pile resistance components. In this section, each combination is called a 'design method'. Six combinations for piles in soils and four combinations for piles socketed in rocks were considered, as shown in Tables 3 and 4 . The calculated total capacity from each 'design method' was compared against the measured pile capacity that was defined using Buildings Department's failure criterion from the pile load tests. The ratio between the measured ultimate pile capacity and the predicted total pile capacity using a particular design method, i.e., the bias factor, measures the degree of deviation of the design method. The mean bias factor $\left(\lambda_{R}\right)$ and the coefficient 
Table 5. First and second moments of the model bias factor for shaft resistance based on the beta method for piles in soils

\begin{tabular}{lcccccccc}
\hline \multirow{2}{*}{ Soil type } & \multicolumn{3}{c}{ Method 1-O'Neill and Reese (1999) } & \multicolumn{3}{c}{ Method 2- $\beta$ method (Hong Kong data) } \\
\cline { 2 - 8 } & No. of cases & Mean & Standard deviation & COV & No. of cases & Mean & Standard deviation & COV \\
\hline Fill & 4 & 3.33 & 1.36 & 0.41 & 7 & 2.06 & 0.77 & 0.37 \\
Alluvium & 3 & 1.32 & 0.12 & 0.09 & 9 & 1.69 & 1.54 & 0.91 \\
Decomposed volcanics & 10 & 0.26 & 0.20 & 0.75 & 10 & 0.57 & 0.22 & 0.39 \\
Decomposed granites & 24 & 0.37 & 0.23 & 0.62 & 5 & 0.77 & 0.33 & 0.43 \\
Saprolites (shaft grouted piles) & 14 & 0.91 & 0.68 & 0.75 & 10 & 1.99 & 1.17 & 0.59 \\
\hline
\end{tabular}

Table 6. First and second moments of the model bias factor for shaft resistance based on empirical correlations with SPT- $N$ for piles in soils

\begin{tabular}{lcccccccc}
\hline \multirow{2}{*}{ Soil type } & \multicolumn{3}{c}{ Method 3- $\tau=1.4 \mathrm{~N}$} & \multicolumn{4}{c}{ Method 4- $\tau=0.8 \mathrm{~N}$} \\
\cline { 2 - 8 } & No. of cases & Mean & Standard deviation & COV & No. of cases & Mean & Standard deviation & COV \\
\hline Fill & 8 & 6.66 & 5.68 & 0.85 & 8 & 11.65 & 9.94 & 0.85 \\
Alluvium & 13 & 3.78 & 2.74 & 0.73 & 13 & 6.62 & 4.80 & 0.73 \\
Decomposed volcanics & 12 & 0.44 & 0.31 & 0.71 & 12 & 0.77 & 0.54 & 0.71 \\
Decomposed granites & 26 & 0.85 & 0.52 & 0.61 & 26 & 1.49 & 0.91 & 0.61 \\
Saprolites (shaft grouted piles) & 15 & 1.82 & 1.12 & 0.62 & 15 & 3.18 & 1.96 & 0.62 \\
\hline
\end{tabular}

Table 7. First and second moments of the model bias factor for shaft resistance based on empirical correlations established in this study for piles in soils

\begin{tabular}{lcccccccc}
\hline \multirow{2}{*}{ Soil type } & \multicolumn{3}{c}{ Method 5-Correlation with SPT-N } & \multicolumn{3}{c}{ Method 6-Correlation with $\sigma_{\mathrm{v}}^{\prime}$} \\
\cline { 2 - 8 } & No. of cases & Mean & Standard deviation & COV & No. of cases & Mean & Standard deviation & COV \\
\hline Fill & 8 & 1.18 & 0.82 & 0.70 & 10 & 1.84 & 1.49 & 0.79 \\
Alluvium & 13 & 0.96 & 0.78 & 0.81 & 15 & 0.96 & 0.90 & 0.94 \\
Decomposed volcanics & 12 & 0.99 & 0.34 & 0.34 & 12 & 0.96 & 0.31 & 0.32 \\
Decomposed granites & 25 & 1.01 & 0.47 & 0.47 & 27 & 0.99 & 0.45 & 0.45 \\
Saprolites (shaft grouted piles) & 15 & 1.00 & 0.50 & 0.50 & 15 & 1.01 & 0.52 & 0.52 \\
\hline
\end{tabular}

Table 8. First and second moments of model bias factor for piles socketed in rocks

\begin{tabular}{lcccccccc}
\hline \multirow{2}{*}{ Design method } & \multicolumn{3}{c}{ Shaft resistance along rock socket } & \multicolumn{3}{c}{ End bearing on rock } \\
\cline { 2 - 8 } & $\begin{array}{c}\text { No. of } \\
\text { cases }\end{array}$ & Mean & $\begin{array}{c}\text { Standard } \\
\text { deviation }\end{array}$ & COV & $\begin{array}{c}\text { No. of } \\
\text { cases }\end{array}$ & Mean & $\begin{array}{c}\text { Standard } \\
\text { deviation }\end{array}$ & COV \\
\hline Method 1-COP (BD 2004a) & 10 & 2.50 & 1.15 & 0.46 & 13 & 2.97 & 1.83 & 0.62 \\
Method 2-O'Neill and Reese (1999) & 8 & 0.96 & 0.31 & 0.32 & 13 & 0.42 & 0.33 & 0.78 \\
Method 3-Correlation with UCS and RQD & 8 & 0.99 & 0.22 & 0.23 & 13 & 1.15 & 0.58 & 0.50 \\
Method 4-Correlation with UCS and RMR & 8 & 0.99 & 0.22 & 0.23 & 8 & 0.98 & 0.25 & 0.25 \\
\hline
\end{tabular}

Table 9. First and second moments of the model bias factor for total capacity of piles in soils

\begin{tabular}{lcccc}
\hline \multicolumn{1}{c}{ Design method } & No. of cases & Mean $^{(*)}$ & Standard deviation ${ }^{(*)}$ & COV $_{\mathrm{R}}{ }^{(*)}$ \\
\hline Method 1-O'Neill and Reese (1999) & 11 & $0.59(0.60)$ & $0.38(0.35)$ & $0.65(0.58)$ \\
Method 2-Hong Kong $\beta$ & 17 & $1.03(1.06)$ & $0.33(0.29)$ & $0.31(0.28)$ \\
Method 3-1.4 N & 11 & $1.14(1.17)$ & $0.72(0.66)$ & $0.64(0.57)$ \\
Method 4-0.8 N & 11 & $1.74(1.79)$ & $1.06(0.96)$ & $0.61(0.54)$ \\
Method 5-Correlation with SPT- $N$ & 11 & $0.97(1.01)$ & $0.44(0.38)$ & $0.45(0.38)$ \\
Method 6-Correlation with $\sigma_{\mathrm{v}}^{\prime}$ & 17 & $0.96(1.00)$ & $0.54(0.51)$ & $0.56(0.51)$ \\
\hline
\end{tabular}

(*) Values in parentheses refer to those when the construction effects are considered at a reference time of 48 hours between the end of excavation and concreting.

of variation $\left(\mathrm{COV}_{\mathrm{R}}\right)$ were calculated for each design method.
Piles in Soils

Table 9 shows the first and second moments of the model bias factor for the 6 design methods in Table 3 . The predicted capacity values based on these different de- 
Table 10. First and second moments of the model bias factor for total capacity of piles on rocks

\begin{tabular}{lcccc}
\hline \multicolumn{1}{c}{ Design method } & No. of cases & Mean & Standard deviation & COV $_{\mathrm{R}}$ \\
\hline Method 1-COP (BD 2004a) & 15 & 2.57 & 0.79 & 0.31 \\
Method 2-O’Neill and Reese (1999) & 15 & 0.48 & 0.25 & 0.52 \\
Method 3-Correlation with UCS and RQD & 15 & 1.23 & 0.43 & 0.35 \\
Method 4-Correlation with UCS and RMR & 8 & 0.90 & 0.32 & 0.35 \\
\hline
\end{tabular}

sign methods are associated with a lower range of $\mathrm{COV}_{\mathrm{R}}$ compared with those of the predicted resistance components presented in Tables 5-7. The error in load transfer measurements and the spatial averaging effects account for this. The $\mathrm{COV}_{\mathrm{R}}$ of the empirical correlations established in this study ranges from 0.45 to 0.56 . The values are comparable to those for empirical correlations derived for driven piles in sand or clay. For instance, the $\mathrm{COV}_{\mathrm{R}}$ of the Meyerhof (1976) correlation for driven piles in sand is 0.5 (Orchant et al., 1988).

Comparing these design methods, the $\beta$-method (Method 2), which follows principles of soil mechanics and is based on Hong Kong data, provides estimates with higher accuracy than the empirical approaches. Among the empirical design methods, Methods 5 and 6 are slightly more accurate than Methods 3 and 4 . The improved performance might come from the consideration of soil types and presence of permanent liners.

Moreover, the COV values for different predictions are approximately $10 \%$ smaller when the construction effects are considered using 48 hours as the reference time between the end of excavation and concreting. The effects are summarized in Table 9. Focusing on Methods 5 and 6, their $\mathrm{COV}_{\mathrm{R}}$ values are reduced from $0.44-0.56$ to 0.38-0.51 after considering the construction effects, and the mean values of the bias factor are brought closer to unity.

\section{Piles on Rocks}

Generally, the total capacity of a large-diameter bored pile socketed in rock includes the shaft resistance along the soil and the rock socket, and the end bearing resistance on the bedrock. Depending on the design rules, not all resistance components may be considered. In the COP method (BD, 2004a), for example, the shaft resistance along the pile shaft in soils is usually ignored. Table 10 shows the statistics of the model bias factor for the four design methods in Table 4.

Method 1 underestimates the total pile capacity systematically and both the socket resistance and the toe resistance are underestimated. Method 2, on the other hand, overestimates the total pile capacity systematically. The overestimation is mainly from the over-prediction of the end bearing resistance, which is associated with a mean bias of 0.42 (Table 8). One reason for such discrepancy is that many of the load tests on the piles socketed in rocks in Hong Kong were not conducted to failure and hence the toe resistance was not fully mobilized. Therefore, the measured total pile capacity was lower than the ultimate total capacity. The correlations with
UCS or RMR established in this paper have model bias factor values closer to unity compared with the COP method.

\section{RELIABILITY OF DESIGN}

After obtaining the values of the first and second moments of the bias factor for each of the design methods in Tables 3 and 4, it is possible to evaluate the reliability of these design methods and to develop partial factors or resistance factors for limit state design using reliability principles. Due to page limit, this paper only attempts to evaluate the reliability of these design methods when a global factor of safety is adopted. Reliability index is adopted to measure the reliability level of a design method. A high reliability index corresponds to a low probability of failure. Consider only the dead and live load effects and assume that both the loads and resistance follow a lognormal distribution. Given the load statistics and load factors, the reliability index $\left(I_{\mathrm{R}}\right)$ for each design method can be calculated using the first order, second moment method (e.g., Withiam et al., 2001; Paikowsky et al., 2004):

$$
I_{\mathrm{R}}=\frac{\ln \left[\frac{\lambda_{\mathrm{R}} F S\left(Q_{\mathrm{D}}+Q_{\mathrm{L}}\right)}{\left(\lambda_{\mathrm{Q}_{\mathrm{D}}} Q_{\mathrm{D}}+\lambda_{\mathrm{Q}_{L}} Q_{\mathrm{L}}\right)} \sqrt{\frac{\left(1+\mathrm{COV}_{\mathrm{Q}_{\mathrm{D}}}^{2}+\mathrm{COV}_{\mathrm{Q}_{\mathrm{L}}}^{2}\right)}{\left(1+\mathrm{COV}_{\mathrm{R}}^{2}\right)}}\right]}{\sqrt{\ln \left[\left(1+\mathrm{COV}_{\mathrm{R}}^{2}\right)\left(1+\mathrm{COV}_{\mathrm{Q}_{\mathrm{D}}}^{2}+\mathrm{COV}_{\left.\mathrm{Q}_{\mathrm{L}}\right)}^{2}\right]\right.}}
$$

where $Q_{\mathrm{L}}$ and $Q_{\mathrm{D}}=$ live load and dead load, respectively; $\mathrm{COV}_{\mathrm{R}}, \mathrm{COV}_{\mathrm{Q}_{D}}$, and $\mathrm{COV}_{\mathrm{Q}_{L}}=$ coefficients of variation of resistance, $Q_{\mathrm{D}}$, and $Q_{\mathrm{L}}$, respectively; $\lambda_{\mathrm{R}}, \lambda_{\mathrm{L}}$, and $\lambda_{\mathrm{D}}=$ mean biases of resistance, live load, and dead load, respectively.

The ratio of dead load to live load is assumed be to 3 in the computation. Table 11 shows the load statistics for building structures suggested by Ellingwood et al. (1980) and the load factors for use in Hong Kong (BD, 2004b). Tables 12 and 13 summarize the calculated values of reliability index for piles in soils and piles socketed in rocks, respectively. A higher reliability index is achieved with a larger mean bias factor or a lower $\mathrm{COV}$ of the design method. The predictions using the $\beta$ values derived based on Hong Kong data for piles in soils and the correlations with UCS and RQD for piles on rocks are associated with reliability index values of 2.90 and 3.11, respectively when a factor of safety of 3.0 is used. Such a reliability level is considered adequate since the target reliability of single bored piles is recommended to be 2.5-3.0 (e.g., Withiam et al., 2001). The reliability level is enhanced with the consideration of adverse construction effects for all design methods for piles in soils. The use of a factor of 
Table 11. Load statistics and load factors for buildings

\begin{tabular}{lccc}
\hline & \multicolumn{2}{c}{ Load statistics } & \\
\cline { 2 - 3 } & (Ellingwood et al. 1980) & $\begin{array}{c}\text { Load factors in Code of } \\
\text { Practice for Structural Use } \\
\text { of Concrete (BD 2004b) }\end{array}$ \\
\hline Dean bias factor & COV & \\
Live load & 1.05 & 0.10 & 1.4 \\
\hline
\end{tabular}

Table 12. Reliability index for piles in soils

\begin{tabular}{lcc}
\hline Design method & $\begin{array}{c}\text { Reliability index } \\
I_{\mathrm{R}}{ }^{(*)} \text { at safety } \\
\text { factor }=2.0\end{array}$ & $\begin{array}{c}\text { Reliability index } \\
I_{\mathrm{R}}{ }^{(*)} \text { at safety } \\
\text { factor }=3.0\end{array}$ \\
\hline Method 1-O'Neill and Reese (1999) & $-0.06(0.05)$ & $0.59(0.75)$ \\
Method 2-Hong Kong $\beta$ & $1.80(2.05)$ & $2.90(3.24)$ \\
Method 3-1.4 N & $1.03(1.22)$ & $1.69(1.94)$ \\
Method 4-0.8 N & $1.80(2.07)$ & $2.48(2.82)$ \\
Method 5-Correlation with SPT- $N$ & $1.16(1.48)$ & $2.01(2.46)$ \\
Method 6-Correlation with $\sigma_{\mathrm{v}}^{\prime}$ & $0.89(1.08)$ & $1.61(1.85)$ \\
\hline
\end{tabular}

(*) Values in parentheses refer to those when the construction effects are considered at a reference time of 48 hours between the end of excavation and concreting.

Table 13. Reliability index for piles socketed in rocks

\begin{tabular}{lcc}
\hline Design method & $\begin{array}{c}\text { Reliability index } \\
I_{\mathrm{R}} \text { at safety } \\
\text { factor }=2.0\end{array}$ & $\begin{array}{c}\text { Reliability index } \\
I_{\mathrm{R}} \text { at safety } \\
\text { factor }=3.0\end{array}$ \\
\hline $\begin{array}{l}\text { Method 1-COP (BD 2004a) } \\
\text { Method 2-O'Neill and Reese (1999) }\end{array}$ & $\begin{array}{c}2.42^{(*)} \\
\begin{array}{l}\text { Method 3-Correlation with UCS } \\
\text { and RQD }\end{array}\end{array}$ & $2.42^{(*)}$ \\
$\begin{array}{l}\text { Method 4-Correlation with UCS } \\
\text { and RMR }\end{array}$ & 1.28 & 0.43 \\
\hline
\end{tabular}

(*) The safe bearing stress is not reduced further (safety factor $=1.0$ ).

safety of 2.0 could lead to too low a reliability level, as shown in Tables 12 and 13. This supports the GEO recommendation (GEO, 2006) that a minimum factor of safety of 3.0 is required for designs based on static analysis only and that a factor of safety of 2.0 can be used only when the design is verified by a sufficient number of load tests. The principle for the use of load tests for design verification has been described by Zhang (2004).

The COP method (Method 1) for piles socketed in rocks uses a set of allowable bearing pressures. It corresponds to a reliability index of $I_{\mathrm{R}}=2.42$, which is not as high as suspected. The $I_{\mathrm{R}}$ value is somewhat underestimated due to the use of the maximum test load as the pile capacity when a load test is not carried out to failure.

\section{CONCLUSIONS}

A database containing information of 62 load tests on large-diameter bored piles in Hong Kong is compiled. The database then serves as the basis for determining the model parameters of several commonly used design methods and for providing performance data for model calibration. Several correlations with SPT- $N$ of soil or UCS of rock have also been established in this paper. The first and second moments of the model bias for these design methods are then obtained by comparing the estimated resistance component or total pile capacity values against the respective measured values. Based on the studies, the following conclusions can be drawn:

1. The model bias both for resistance components and for the total pile capacity is evaluated. The degree of discrepancy of the predictions of pile resistance components is higher than that of the total capacity of piles both in soils and socketed in rocks. The error in load transfer measurements and the spatial averaging effects account for this.

2. The use of permanent liners, pile-shaft grouting, and the time delay between the end of pile excavation and pile concreting can affect the magnitude of shaft resistance significantly. The construction effects associated with the use of permanent liners and pile-shaft grouting are included in the derivation of the beta method and the empirical correlations. The $\mathrm{COV}$ values of the design methods for piles in soils are approximately $10 \%$ lower when the construction time effects are considered using 48 hours as the reference time between the end of excavation and concreting. Greater attention should be paid to better understand the construction effects.

3. The beta method based on Hong Kong data and the correlations with UCS and RQD established in this paper are suggested for floating piles and piles socketed in rocks, respectively. These methods are associated with appropriate mean bias factors and fairly low $\mathrm{COV}_{\mathrm{R}}$ values.

4. When adopting a factor of safety of 3.0, the reliability indices of the beta method and the correlations established in this paper for single floating piles and piles socketed in rocks are 2.90 and 3.11, respectively, which are considered to be adequate. The COP method (Method 1) for piles socketed in rocks uses a set of allowable bearing pressures. It corresponds to a reliability index of $I_{\mathrm{R}}=2.42$, which is somewhat underestimated due to the use of the maximum test load as the pile capacity when a load test is not carried out to failure.

\section{ACKNOWLEDGEMENT}

The work reported in this paper is substantially supported by the Research Grants Council of the Hong Kong SAR (Project HKUST6126/03E).

\section{REFERENCES}

1) Becker, D. E. (1996): Eighteenth Canadian geotechnical colloquium: limit states design for foundations, Part I: An overview of the foundation design process, Canadian Geotechnical Journal, 33(6), 956-983.

2) Bieniawski, Z. T. and Orr, C. M. (1976): Rapid site appraisal for dam foundation by the geomechanics classification, Transactions of the 12th International Congress on Large Dams, Mexico, 2(Q46, R32), 483-500.

3) Brinch Hansen, J. (1963): Discussion of 'Hyperbolic stress-strain 
response: cohesive soil' by R. L. Kondner, Journal of Soil Mechanics and Foundation Engineering Division, ASCE, 89(4), 241-242.

4) Buildings Department (2004a): Code of Practice for Foundations, Buildings Department, Hong Kong.

5) Buildings Department (2004b): Code of Practice for Structural Use of Concrete, Buildings Department, Hong Kong.

6) Chan, W. F., Chan, K. H. and Tse, C. M. (2002): Design and construction of bored piles in completely or moderately decomposed rock for the KCRC Ma On Shan Rail, Proc. 22nd Annual Seminar, Geotechnical Division, Hong Kong Institution of Engineer, 73-86.

7) Ellingwood, B., Galambos, T. V., MacGregor, J. G. and Cornell, C. A. (1980): Development of a Probability Based Load Criterion for American National Standard A58, NBS Special Report 577, U.S., Department of Commerce, National Bureau of Standards, 222.

8) Foye, K. C., Salgado, R. and Scott, B. (2006): Resistance factors for use in shallow foundation LRFD, Journal of Geotechnical and Geoenvironment Engineering, ASCE, 132(9), 1208-1218.

9) Fraser, R. A. (1985): Design of bored piles, Hong Kong Engineer, $37-52$.

10) Fraser, R. A. and Kwok, D. (1986): Mobilisation of skin friction in bored piles in Hong Kong, Proc. International Conference on Deep Foundations, Beijing, 2, 2.65-2.74.

11) Geotechnical Engineering Office (GEO) (2006): Foundation Design and Construction, GEO Publication No. 1/2006, Geotechnical Engineering Office, Hong Kong.

12) Holt, D. N., Lumb, P. and Wong, P. K. K. (1982): Site control and testing of bored piles at Telford Gardens, an elevated township at Kowloon Bay, Hong Kong, Proc. 7th Southeast Asian Geotechnical Conference, Hong Kong, 1, 349-361.

13) Honjo, Y. and Nagao, T. (2007): Development of a basic specific design code on performance based specification concept: The Technical Standards for Port and Harbor Facilities (2007), Proc. 1st International Symposium on Geotechnical Safety and Risk (ed. by H. W. Huang and L. M. Zhang), 18-19 Oct. 2007, Tongji University, Shanghai, China, 105-115.

14) Honjo, Y., Suzuki, M., Shirato, M. and Fukui, J. (2002): Determination of partial factor for a vertically loaded pile based on reliability analysis, Soils and Foundations, 42(4), 91-109.

15) Hope, S., Young, S. and Dauncey, P. (2000): Airport railway pile tests, Millennium Collection of Hong Kong Geotechnical Papers (1973-2001), The Hong Kong Institution of Engineers, Hong Kong.

16) Horvath, R. G. and Kenney, T. C. (1979): Shaft resistance of rocksocketed drilled piers, Symposium on Deep Foundations (ed. by Fuller), ASCE, Atlanta, 182-214.

17) Kuo, C. L., McVay, M. C. and Birgisson, B. (2002): Calibration of load and resistance factor design-resistance factors for drilled shaft design, Transportation Research Record 1808, Paper No. 02-23759.

18) Linney, L. F. (1983): A review of the geotechnical aspects of the construction of the first phase of the mass transit railway, Hong Kong, Quarterly Journal of Engineering Geology, 16, 87-102.

19) Littechild, G. D., Plumbridge, G. D. and Free, M. W. (1998): Shaft grouted piles in sand and clay in Bangkok, Proc. 7th International Conference and Exhibition on Piling and Deep Foundations, 1998, Vienna, Austria.

20) Lo, S. C. R. and Li, K. S. (2003): Influence of a permanent liner on the skin friction of large-diameter bored piles in Hong Kong Granitic Saprolites, Canadian Geotechnical Journal, 40, 793-805.

21) Meyerhof, G. G. (1976): Bearing capacity and settlement of pile foundations, Journal of the Geotechnical Engineering Division, ASCE, 102(3), 197-228.

22) Ng, C. W. W., Yau, T. L. Y., Li, J. H. M. and Tang, W. H. (2001): New failure load criterion for large-diameter bored piles in weathered geomaterials, Journal of Geotechnical and Geoenvironmental Engineering, ASCE, 127(6), 488-498.

23) O'Neill, M. W. (1999): Some effects of construction on the performance of deep foundations, Geotechnical Special Publication No 88, ASCE (ed. by J. M. Roesset), Reston, VA, 196-215.

24) O'Neill, M. W. (2001): Side resistance in piles and drilled shafts (39th Terzaghi lecture), Journal of Geotechnical and Geoenviron- mental Engineering, ASCE, 127(1), 1-16.

25) O'Neill, M. W. and Hassan, K. H. (1994): Drilled shafts: effects of construction on performance and design criteria, Proc. International Conference on Deep Foundations, 1, Federal Highway Administration, Orlando, 137-187.

26) O'Neill, M. W. and Reese, L. C. (1999): Drilled Shafts: Construction Procedures and Design, Report FHWA-IF-99-025, Federal Highway Administration, McLean, Virginia.

27) Orchant, C. J., Kulhawy, F. H. and Trautmann, C. H. (1988): Reliability-based Foundation Design for Transmission Line Structures, Vol. 2: Critical Evaluation of In-situ Test Methods, EL-5507 Final Report, Electrical Power Institute, Palo Alto, CA.

28) Paikowsky, S. G., Birgisson, B., Mcvay, M. C., Nguyen, T., Kuo, C., Baecger, G., Stenersen, K., O’Malley, K., Chernauskas, L. and O'Neill, M. W. (2004): Load and resistance factor design (LFRD) for deep foundations, NCHRP Report 507, Transportation Research Board, National Research Council, Washington, D.C.

29) Phoon, K. K. and Kulhawy, F. H. (2005): Characterisation of model uncertainties for laterally loaded rigid drilled shafts, Geoetechnique, 55(1), 45-54.

30) Plumbridge, G. D., Littlechild, B. D., Hill, S. J. and Pratt, M. (2000): Full scale shaft grouted barrette in Hong Kong-A first, Proc. 20th Annual Seminar, Geotechnical Division, Hong Kong Institution of Engineer, 159-166.

31) Poulos, H. G. and Davis, E. H. (1980): Pile Foundation Analysis and Design, John Wiley and Sons, New York.

32) Schuppener, B. (2007): Eurocode 7 and its latest developments, Proc. Ist International Symposium on Geotechnical Safety and Risk (ed. by H. W. Huang and L. M. Zhang), 18-19 Oct. 2007, Tongji University, Shanghai, China, 117-132.

33) Silva, S. D., Cheung, C. T., Pratt, M. and Walsh, N. (1998): Instrumental bored and barrette pile for Western Habour Crossing, Geotechnical Aspects of the Airport Core Project, Geotechnical Division, Hong Kong Institution of Engineers, Hong Kong, 77-94.

34) Withiam, J. L., Voytko, E. P., Barker, R. M., Duncan, J. M., Kelly, B. C., Musser, S. C. and Elias, V. (2001): Load and Resistance Factor Design (LRFD) for Highway Bridge Substructures, Publication No. FHWA HI-98-032, Federal Highway Administration, Washington, D.C.

35) Zhan, C. Z. and Yin, J. H. (2000): Field static load tests on drill shaft founded on or socketed into rock, Canadian Geotechnical Journal, 37, 1283-1294.

36) Zhang, L. M. (2004). Reliability verification using proof pile load tests, Journal of Geotechnical and Geoenvironmental Engineering, ASCE, 130(11), 1203-1213.

37) Zhang, L. M. and Chu, L. F. (2009): Calibration of methods for designing large-diameter bored piles: Serviceability limit state, Soils and Foundations, 49(6), 897-908.

38) Zhang, L. M. and Tang, W. H. (2001): Bias in axial capacity of single bored piles arising from failure criteria, Structural Safety and Reliability ICOSSAR'01 (ed. by Corotis, Schueller and Shinozuka), A. A. Balkema Publishers, Lisse, in CD Rom.

39) Zhang, L. M., Li, D. Q. and Tang, W. H. (2005): Reliability of bored pile foundations considering failure criteria, Canadian Geotechnical Journal, 42, 1086-1093.

40) Zhang, L. M., Li, D. Q. and Tang, W. H. (2006): Impact of routine quality assurance on reliability of bored piles, Journal of Geotechnical and Geoenvironmental Engineering, ASCE, 132(5), 622-630.

41) Zhang, L. M., Tang, W. H. and Ng, C. W. W. (2001): Reliability of axially loaded driven pile groups, Journal of Geotechnical and Geoenvironmental Engineering, ASCE, 127(12), 1051-1060.

42) Zhang, L. M., Tang, W. H. and Zhang, L. L. (2002): Reliabilitybased design of large-diameter bored piles in Hong Kong-Part 1: Evaluation of design methods, Proc. International Workshop on Foundation Design Codes and Soil Investigation in View of International Harmonization and Performance Based Design (ed. by Y. Honjo, O. Kusakabe, K. Matsui, M. Kouda and G. Pokharel), Kamakura, Japan, A. A. Balkema, 263-271. 